\title{
Sistem Informasi Penyaluran Beras Miskin (Raskin) Kelurahan Desa Silau Malela Kabupaten Simalungun
}

\author{
Heru Satria Tambunan 1 , Sumarno², Indra Gunawan² \\ ${ }^{1}$ Sistem Informasi, STIKOM Tunas Bangsa, Pematangsiantar, Indonesia \\ ${ }^{2}$ Teknik Informatika, STIKOM Tunas Bangsa, Pematangsiantar, Indonesia \\ Email: heru@amiktunasbangsa.ac.id, sumarno@amiktunasbangsa.ac.id,indra@amiktunasbangsa.ac.id
}

\begin{abstract}
Abstrak-Kantor Kelurahan Desa Silau Malela Kabupaten Simalungun dalam mekanisme distribusi penyaluran beras miskin terdapat banyak proses pendataan baik menggunakan teknologi komputer yang menggunakan Microsoft exel, maupun secara konvensional yang terkadang menemui masalah dalam proses transaksi penyaluran beras raskin yang mengakibatkan sering terjadinya redudansi data serta dalam proses pencarian data yang membutuhkan waktu yang cukup lama. Karena itulah, penulis ingin membuat aplikasi Sistem Informasi Penyaluran Beras Miskin (Raskin) Pada Kantor Kelurahan Desa Silau Malela Kabupaten Simalungun dengan menggunakan aplikasi Adobe Dreamweaver CS6 dan database MySQL. Metode pengembangan Sistem yang digunakan yaitu dengan metode Waterfall. Dengan adanya Sistem Informasi ini penginputan, pencarian serta laporan dapat dilakukan dengan cepat dan akurat karena data-data tersimpan dengan aman dan terstruktur.
\end{abstract}

Kata Kunci: Sistem Informasi, Penyaluran, Raskin, Adobe Dreamweaver CS6, MySQL

Abstrack-Village Office Village Glare Malela Simalungun in the distribution mechanism distributing rice for the poor there are many processes of data collection using either a computer technology that uses Microsoft Exel, and conventionally sometimes encounter problems in the process of distribution transaction poor rice resulting in frequent occurrence of data redundancy and data collection which takes quite a long time. Therefore, the author wants to make the application of Information Systems Distribution of Rice Poor (Raskin) In the Village Office Village Glare Malela Simalungun using Adobe Dreamweaver CS6 application and database MySQL. System development method used is by the Waterfall method. Given this information system inputting, searching and reporting can be performed quickly and accurately because the data is stored securely and structured.

Keywords: Information Systems, Distribution, Raskin, Adobe Dreamweaver CS6, MySQL

\section{PENDAHULUAN}

Dalam sebuah perusahaan, penggunaan teknologi informasi sangat penting untuk menunjang perkembangan organisasi dari sisi kegiatan operasional. Hal ini dikarenakan dengan adanya suatu sistem pengarsipan dokumen pada suatu organisasi, maka dapat mempercepat suatu proses kerja dan dapat memudahkan dalam mengelola dokumen serta menjadikan dokumen menjadi lebih teratur dan rapi.

Program kebijakan beras untuk Rumah tangga miskin (Raskin) adalah bagian dari upaya Pemerintah Indonesia untuk memberdayakan masyarakat dengan menanggulangi masalah kemiskinan secara terpadu. Penelitian ini bertujuan untuk mendapatkan gambaran implementasi kebijakan program beras untuk rumah tangga miskin. Raskin merupakan subsidi pangan pokok dalam bentuk beras yang diperuntukkan bagi keluarga miskin sebagai upaya dari pemerintah untuk meningkatkan ketahanan pangan dan memberikan perlindungan pada keluarga miskin. Beras merupakan makanan pokok sebagian besar penduduk Program Raskin yang merupakan implementasi dari konsistensi pemerintah dalam rangka memenuhi hak pangan masyarakat.

Banyaknya masyarakat yang ingin mendapatkan beras raskin sehingga suit untuk memilih siapa yang akan berhak mendapatkan beras tersebut, dan banyak system penyaluran beras raskin tersebut tidak tepat sasaran.

\section{METODE PENELITIAN}

\subsection{Sistem}

Sistem adalah suatu jaringan kerja dari prosedur-prosedur yang saling berhubungan, berkumpul bersama-sama untuk melakukan suatu kegiatan atau menyelesaikan suatu sasaran tertentu [1].

\subsection{Informasi}

Informasi adalah data yang sudah diolah dengan cara tertentu menjadi bentuk yang sesuai dengan keperluan penggunaan informasi bersangkutan [2]

\subsection{Sistem Informasi}

Sistem adalah seperangkat komponen yang saling berinteraksi, saling terkait, saling bergantung yang berfungsi secara keseluruhan untuk mencapai tujuan tertentu. Sistem yang efektif harus sinergis [3].

\subsection{Raskin}

Beras Miskin (Raskin) merupakan program bantuan sosial pemerintah yang bertujuan menunjang kebutuhan dasar masyarakat yang hidup di daerah dengan tingkat kemiskinan tinggi [4]. 


\subsection{Metode Pengumpulan Data}

Untuk menyelesaikan Tugas Akhir ini, penulis melakukan metode pengumpulan data sebagai berikut :

1. Pengelompokan data

Adapun pengelompokan data yang penulis lakukan dalam penelitian ini adalah menurut Sumber pengambilannya, penulis menggunakan Data Asli yaitu data yang diperoleh langsung dilapangan oleh penulis.

2. Teknik Pengumpulan data

Adapun teknik pengumpulan data yang digunakan adalah Observasi yaitu pemilihan, pengubahan, pencatatan, dan pengkodean serangkaian perilaku dan suasana yang berkenaan dengan organisme (melalui situasi alamiah), sesuai dengan tujuan-tujuan empiris.

\subsection{Metode Perancangan Sistem}

Metode perancangan sistem digunakan dalam membangun sistem, diantaranya membangun proses, rancangan output, rancangan input, rancangan database, rancangan sistem dan rancangan interface.

a. Rancangan Proses

Rancangan proses dimodelkan dengan data flow diagram (DFD). Perancangan DFD merupakan hal yang harus dilakukan karena dengan melihat DFD maka kita akan mengetahui arus data yang mengalir dalam suatu sistem dan mengimplementasikannya pada sebuah database.

1. Perancangan DFD Level 0

Adapun perancangan DFD level 0 dari Sistem Informasi Penyaluran Beras Miskin (RASKIN) Pada Kantor Kelurahan Desa Silau Malela Kabupaten Simalungun adalah seperti gambar 1. dibawah ini:

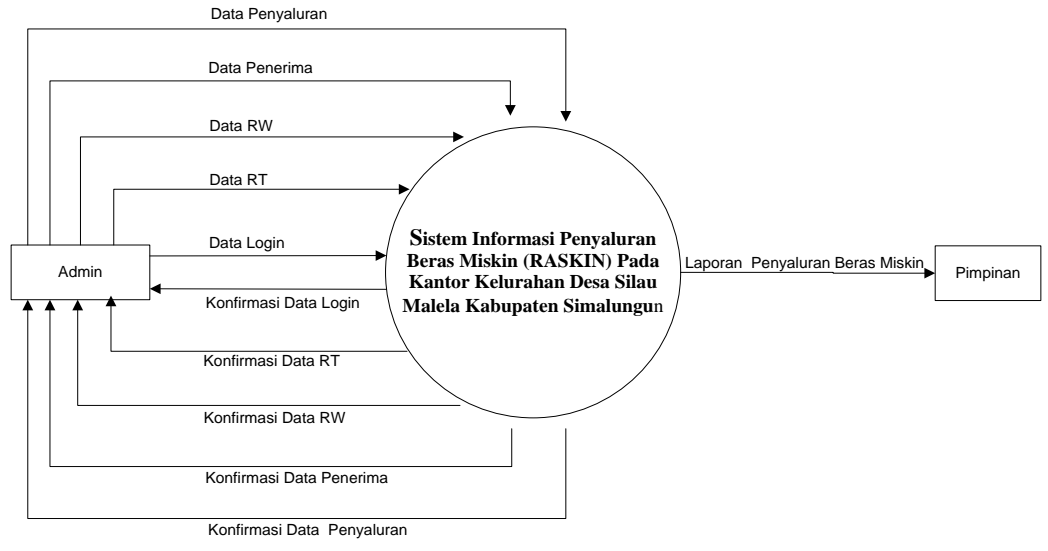

Keterangan:

Gambar 1. DFD Level 0

a. Proses Mengolah Data RT

Pada proses mengolah RT, Admin memasukkan RT. Diolah dan disimpan di dalam Database System. Selanjutnya RT tersebut akan dikonfirmasi kepada Admin.

b. Proses Mengolah Data RW

Pada proses mengolah Data RW, Admin memasukkan Data RW. Diolah dan disimpan di dalam Database System. Selanjutnya Data RW tersebut akan dikonfirmasi kepada Admin.

c. Proses Mengolah Data Penerima

Pada proses mengolah Data Penerima, Admin memasukkan Data Penerima. Diolah dan disimpan di dalam Database System. Selanjutnya Data Penerima tersebut akan dikonfirmasi kepada Admin.

d. Proses Mengolah Data Penyaluran

Pada proses mengolah Data Penyaluran, Admin memasukkan Data Penyaluran. Diolah dan disimpan di dalam Database System. Selanjutnya Data Penyaluran n tersebut akan dikonfirmasi kepada Admin.

e. Proses Mengolah Data Laporan.

Pada proses mengolah Data Laporan, Admin memasukkan Data Penyaluran. Diolah dan disimpan di

\section{ANALISA DAN PEMBAHASAN}

Merupakan rancangan Sistem Informasi Penyaluran Beras Miskin (RASKIN) Pada Kantor Kelurahan Desa Silau Malela Kabupaten Simalungun yang dimodelkan dengan bagan berikut ini. 


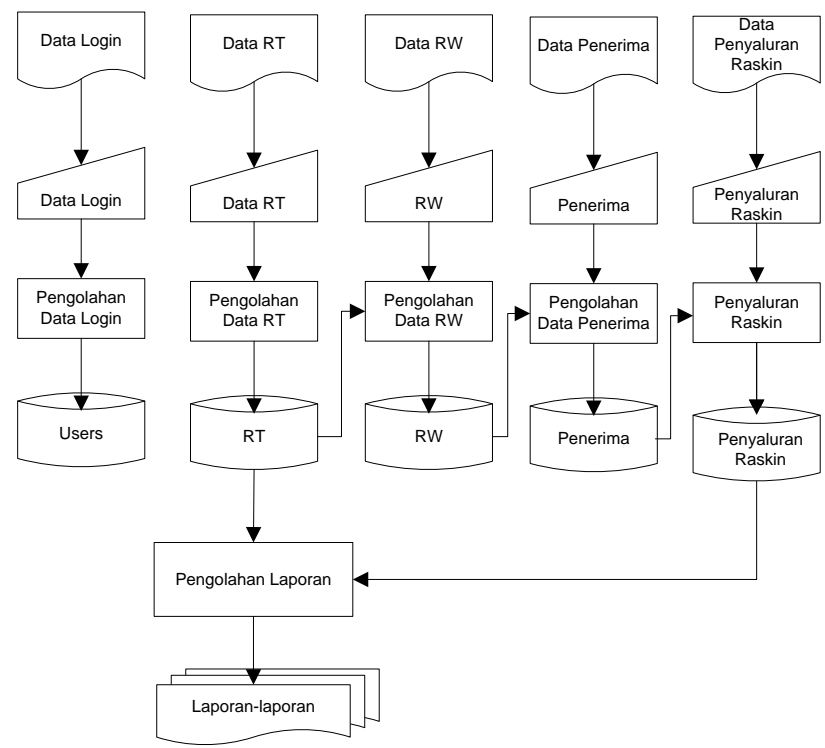

Gambar 2. Flowchart Sistem

Dalam pembahasan ini menjelaskan tentang prosedur kerja sistem, spesifikasi kebutuhan sistem, serta kelemahan dan kelebihan sistem.

a. Prosedur Kerja Sistem

Adapun prosedur kerja Sistem Informasi Penyaluran Beras Miskin (RASKIN) Pada Kantor Kelurahan Desa Silau Malela Kabupaten Simalungun ini adalah sebagai berikut:

1. Admin menggunakan komputer untuk memulai / start sistem.

2. Setelah dijalankan akan tampil Halaman Utama.

3. Pilih menu Login.

4. Setelah itu, masukkan Username dan Password yang anda miliki. Jika Username dan Password anda telah terdaftar di dalam database system maka anda akan masuk ke dalam Halaman Utama RT, RW, Penerima ataupun Penyaluran Raskin tergantung dengan akun yang anda masukkan. Namun anda akan tetap berada di halaman login jika username dan password yang anda masukkan salah.

5. Selanjutkan akan terdapat link-link tertentu pada Halaman Utama masing-masing yang selanjutnya digunakan untuk mengolah dan memanipulasi data. Alur kerja sistem dapat dilihat pada gambar 3. berikut ini.

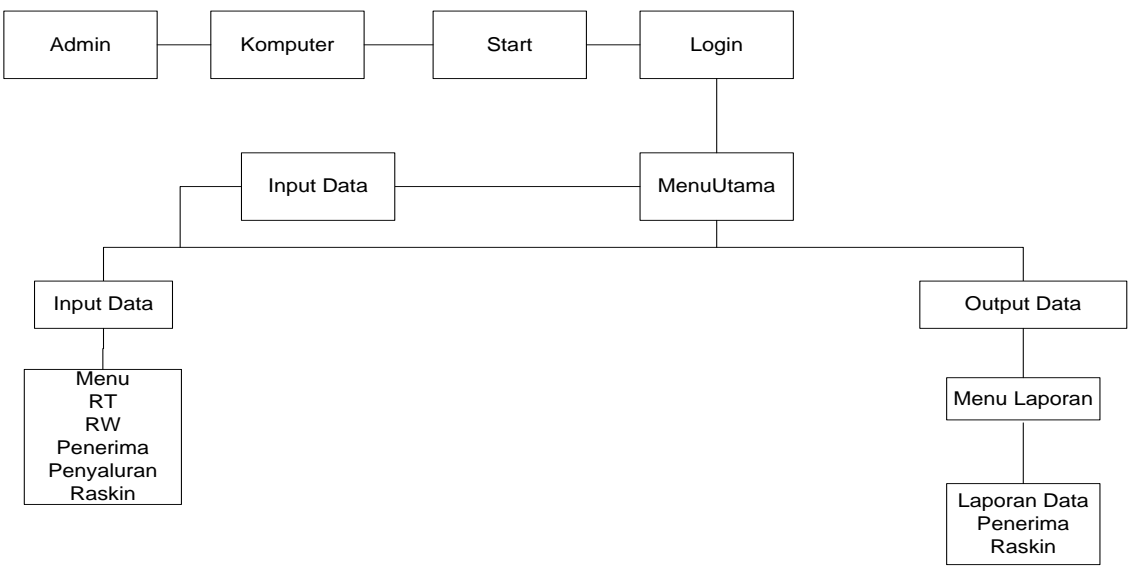

Gambar 3. Alur Prosedur Kerja Sistem

\section{IMPLEMENTASI}

Sistem yang sudah dirancang selanjutnya akan diteruskan ke tahap pengimplementasian sistem. Berisikan tampilan eksekusi program yang meliputi form (input sistem) dan report (output sistem) yang sudah berisikan data.

\section{a. Masukan (Input) Sistem}

Sistem Informasi Penyaluran Beras Miskin (RASKIN) Pada Kantor Kelurahan Desa Silau Malela Kabupaten Simalungun yang telah dibentuk memiliki halaman masukan yang digunakan untuk menginput data, diantaranya: 
1. Halaman Input Data RT

Digunakan untuk menginput Data RT. Tampilan Halaman Input Data RT dapat dilihat pada gambar 4 berikut ini.

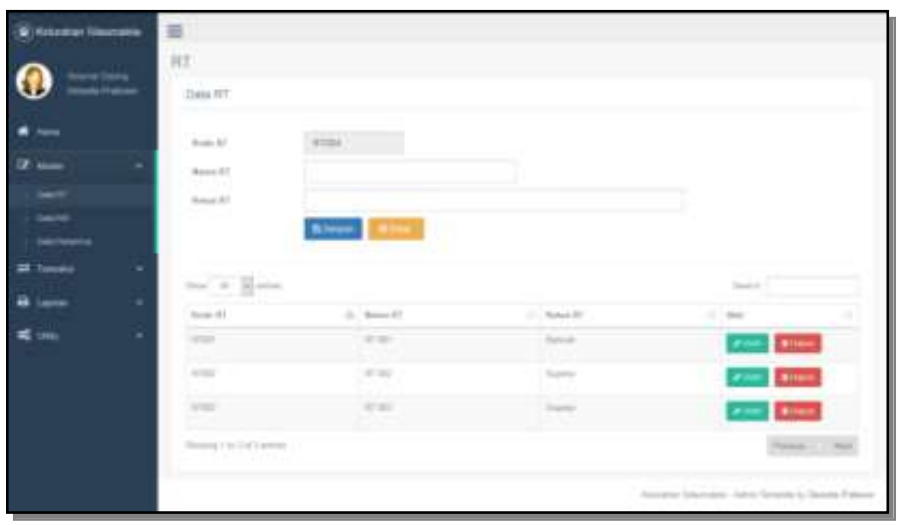

Gambar 4. Tampilan Halaman Input Data RT

2. Halaman Input Data RW

Digunakan untuk menginput Data RW. Tampilan halaman Input Data RW dapat dilihat pada gambar 5 dibawah ini :

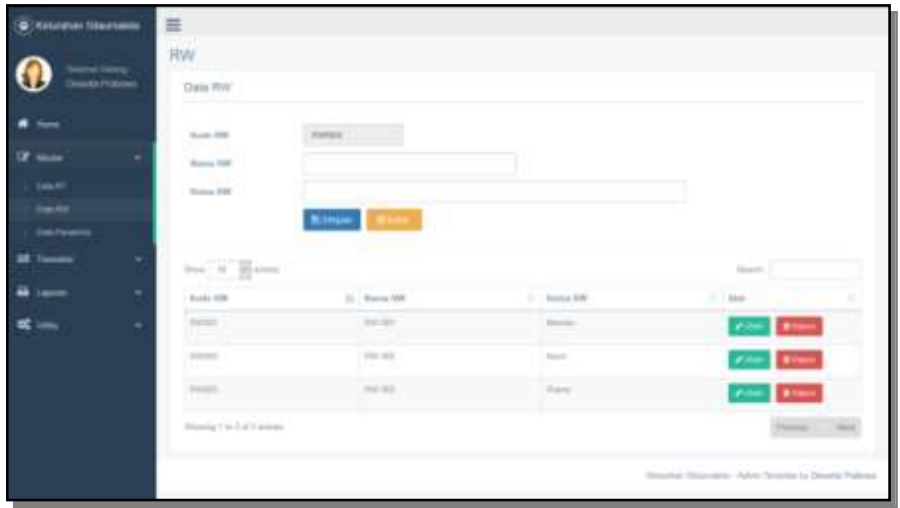

Gambar 5. Tampilan Halaman Input Data RW

3. Halaman Input Data Penerima

Digunakan untuk menginput Data Penerima. Tampilan Halaman Input Data Penerima dapat dilihat pada gambar 6 dibawah ini.

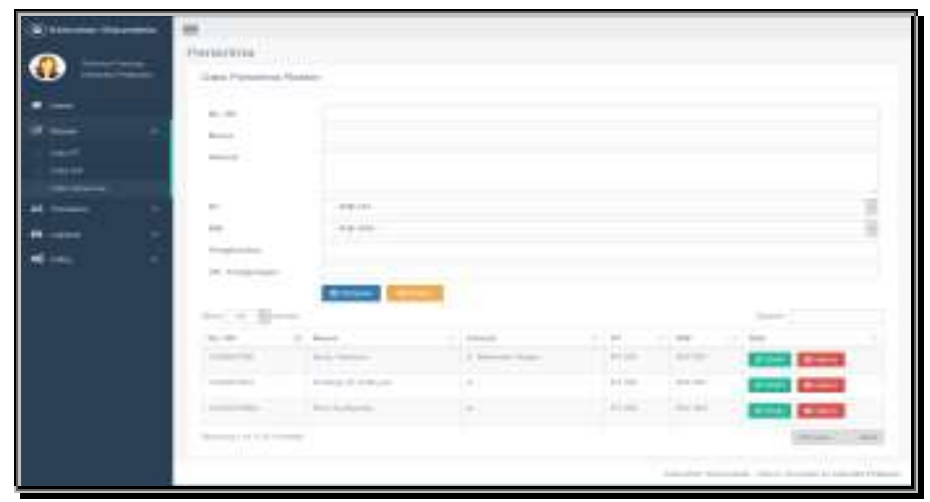

Gambar 6. Tampilan Halaman Input Data Penerima

4. Halaman Input Transaksi Penyaluran

Digunakan untuk menginput Transaksi Penyaluran. Tampilan Halaman Input Transaksi Penyaluran dapat dilihat pada gambar 7 dibawah ini. 


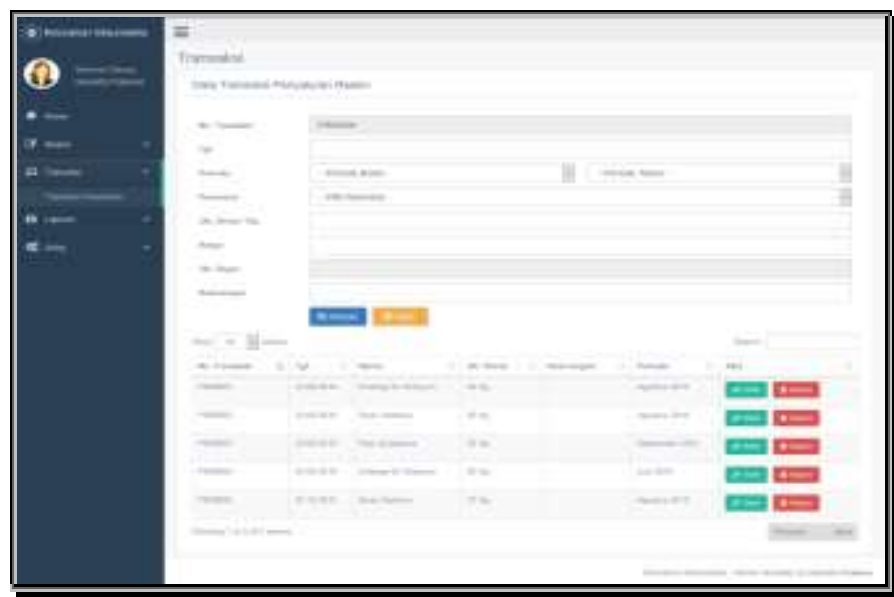

Gambar 7. Tampilan Halaman Input Transaksi Penyaluran

\section{b. Keluaran (Output) Sistem}

Sistem Informasi Penyaluran Beras Miskin (RASKIN) Pada Kantor Kelurahan Desa Silau Malela Kabupaten Simalungun yang telah dibangun memiliki halaman beberapa keluaran (output) yaitu:

Halaman Laporan Data Stok Beras digunakan untuk menampilkan Laporan Data Stok Beras yang telah tersimpan di dalam database system. Tampilan halaman Laporan Data Stok Beras dapat dilihat pada gambar 8 dibawah ini:

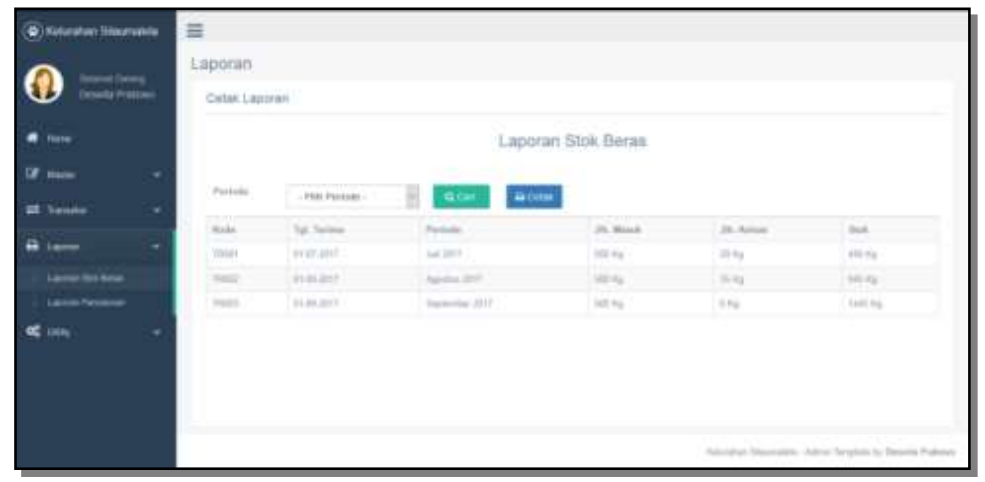

Gambar 8. Tampilan Halaman Cetak Laporan

\section{KESIMPULAN}

Berikut ini adalah beberapa kesimpulan dari Tugas Akhir Saya yaitu sebagai berikut:

1. Program ini dibangun dengan menggunakan Macromedia Dreamweaver CS 6 dan database MySQL.

2. Sistem Informasi Penyaluran Beras Miskin (RASKIN) Pada Kantor Kelurahan Desa Silau Malela Kabupaten Simalungun yang dibuat adalah sebagai pengganti buku dan kini menggunakan sistem komputerisasi maka proses penginputan dan pencarian data akan secara cepat karena data-data disimpan dengan aman dan terstruktur serta tidak terjadi lagi keterlambatan dalam pencarian data.

3. Dengan dibangunnya Sistem Informasi Penyaluran Beras Miskin (RASKIN) Pada Kantor Kelurahan Desa Silau Malela Kabupaten Simalungun,

\section{REFERENCES}

[1] A. Anisah and K. Kuswaya, "Analisis Dan Perancangan Sistem Informasi Pengolahan Data Pengeluaran, Penggunaan Bahan Dan Hutang Dalam Pelaksanaan Proyek Pada Pt Banamba Putratama," Simetris J. Tek. Mesin, Elektro dan Ilmu Komput., vol. 8, no. 2, p. 507, 2017.

[2] T. A. Wicaksono and S. Amanah, "Sistem informasi pengelolaan raskin pada pelaksana distribusi raskin desa jatingarang," vol. 5, no. 1, pp. 34-43, 2018.

[3] C. E. Suharyanto, J. E. Chandra, and F. E. Gunawan, "Perancangan Sistem Informasi Penggajian Terintegrasi Berbasis Web (Studi Kasus di Rumah Sakit St. Elisabeth)," J. Nas. Teknol. dan Sist. Inf., vol. 3, no. 2, pp. 225-232, 2017.

[4] Kamaruddin Tone, "RANCANG BANGUN SISTEM INFORMASI DISTRIBUSI BANTUAN SOSIAL BERAS MISKIN (STUDI KASUS KECAMATAN BINAMU KABUPATEN JENEPONTO),” vol. 1, 2016. 